\title{
DEVELOPING VOCABULARY BOOK BASED ON CROSSWORD PUZZLE FOR VOCABULARY MASTERY AS MEDIA OF VOCABULARY INSTRUCTION FOR JUNIOR HIGH SCHOOL
}

\author{
Agatha Tantri Windu Sari ${ }^{1}$ \\ Aulia Hanifah Qomar ${ }^{2}$ \\ Universitas Muhammadiyah, Metro \\ E-mail: aulya_moetz@yahoo.com
}

\begin{abstract}
The main objective of the research is to develop picture media for vocabulary mastery based on crossword puzzle as a media of vocabulary instruction. The research was a research and development (R\&D) study. This research is formative research. The steps in this research were conducting selfevaluation, getting expert review and one-to-one, small group, and filed test. The research object of this study is students of eight grade in SMP Muhammadiyah 3 Metro and SMP Negeri 10 Metro. The result of the study showed that by using vocabulary book based on crossword puzzle is very good and can help students in learning vocabulary and the students got a new knowledge.
\end{abstract}

Keyword: Crossword Puzzle, Vocabulary Mastery, Vocabulary Instruction

\section{INTRODUCTION}

In learning English, vocabulary is the most important that the students have a clear idea of what they are trying to learn. Knowing the word is essential in order to make sentences which are used in conveying all the information. Automatically, a good communication is the result of information. Besides, it just made us clear when we could conduct interactions. Moreover we have a large number of the word, we can communicate effectively, efficiently, and smoothly. The way to improve the ability of the students in English is very hard, so the vocabulary mastery is very important to be learnt. Language is very important in communication and the students cannot understand what other people said, if they do not have many vocabularies.

The ability of teachers in English language learning, is often inadequate to meet the demands of students, especially students who have a high ability to speak and had no means of learning more advanced than his own teacher. Teaching and learning systems are often monotonous, less variety and less attractive so that students become bored, not interested in learning. In language learning includes four aspects, such as: listening, speaking, reading and writing. Those aspects, in general, students less read, this is 
seen when students do repeat, they tend to work on the problems that others first rather than questions regarding the content of the discourse comprehension (Reading comprehension), because there are many students who do not have English vocabulary sufficient to understand the content of the discourse. The vocabulary is one of the important components in English teaching in addition to other components such as structure, pronunciation and intonation. Vocabulary has a vital role, because if a student is weak in vocabulary, students can not communicate thoughts and ideas clearly as wants both oral and written. Similarly, students can not better understand the content of the text discourse, because he lacked the vocabulary forming sentences spoken orally and in writing and to read and listen to the news or conversations from various sources.

One of the media used in English learning is vocabulary book based on crossword puzzle, this media is relevant and good for student for memorizing and get many new vocabulary with fast way. By using vocabulary book based on crossword puzzle will be easy to remember the lesson because more practices and enjoyable. The researcher chooses this method because it is suitable for teaching foreign language especially in English. In conclusion, the researcher wants to develop an English vocabulary learning media focusing in teaching by using vocabulary book based on crossword puzzle.

\section{THEORETICAL REVIEW}

\section{Concept of Vocabulary}

According Hatch and Brown (1995; 25 ) the first type of vocabulary refers to the one that the students have been taught and that they are expected to be able to use. Meanwhile, the second one refers to the words which the students will recognize when they meet them, but which they will probably not be able to pronounce. There are two kinds of vocabulary, namely receptive vocabulary and productive vocabulary.

\section{Receptive Vocabulary}

Receptive vocabulary is words that learners recognize and understand when they are used in context, but which they cannot produce. It is vocabulary that learners recognize when they see or meet in reading text but do not use it in speaking and writing.

\section{Productive Vocabulary}

Productive vocabulary is the words that the learners understand and can pronounce correctly and use constructively in speaking and writing. It involves what is needed for receptive vocabulary plus the ability to speak or write at the appropriate time. Therefore, productive vocabulary can be addressed as an active process, because the learners can produce the words to express their thoughts to others.

\section{Concept of Vocabulary Mastery}

According to Coady and Huckin $(1997 ; 25)$, vocabulary is central to language and critical importance to the typical language learner it means that the learner should master the 
vocabulary so that they can learn or understand the language. Ricard $(2006 ; 7)$, states that vocabulary is the total number of the words which (with rules for combining them) make up a language this statement is then strengthened by burns who says that vocabulary means the stock of words used by person.

Literacy vocabulary is very important in the language and vocabulary can be used to communicate with other people and then to be able to deliver something to the other well. There are some words in a sentence and those collections of the words arrange in alphabetical order and explained. Those word chould be noun, verb, adjective, adverb, conjuction pronoun etc.

\section{Concept of Students'Vocabulary Mastery}

Vocabulary is one of essential aspect in learning of foreign language, especially in English language. So if the students knows lot of words, they will be easy to understand something in English. Vocabulary is central language and critical important to the typical language learner. Furthemore, Wallace $(1988 ; 30)$ states that vocabulary is the stock of words used by the people, a particular class of people even person, it is the essential aspect of the use in language. Vocabulary is the fundamental thing everyone who want to speak well. Vocabulary is the vital or important of the language. By mastering vocabulary, people will understand what someone says easly. Vocabulary is component that very essential in English. It is imposible if the students can't mastery vocabulary they will understand in English.

Based on explanation above, it can be conclude that vocabulary is a list of words that have meaning and usually used in language. Vocabulary is also basic requirement to make communication and if someone master in vocabulary, they can understand and speak well in foreign language. It make easy to communicate to other people in every aspect in the world. The more vocabulary they have, the more skillful the students perform the language.

\section{Concept of Media}

There are a lot of media. Daryanto $(2013 ; 4)$ media is plural form from medium. Medium means intermediatery that through out of communication between sender and receiver. It's mean that media is one of communication component that carry out message from sender to receiver. Media is anything used to send message(s) from the sender(s) to the receiver(s), so it can be aroused the learners' thought, feeling, and interest to gear students' learn.

According to Ruis $(2009 ; 3)$ media is very useful in learning the english language. Teachers and learners are helped by using media to achieve the learning aims. So, the teachers should apply the media in teaching - learning process because :

a. Instructional media can be solved the lack of the learners' experiences. Learners have different background such as family life, and social 
economic. Learners who live at different areas will have different experience. Media can help them to achieve learning goals.

b. Instructional media can be reached everything out of class. The Theachers use a picture to present things which can not be brought into the classroom such as: planes, elephants, stations, or markets.

c. Instructional media are created the possible direct interacting between the learners and their environment.

d. Media are produced some observation. The learners' observation can be directed into the important things based on the teachers aims.

e. Media can be kept the basic, concrete and real concept of the teaching.

f. The learners' motivation are aroused by using media in learning.

g. Media are integrated the experience from the concerete things to the abstract ones.

\section{Concept of Using Crossword Puzzle}

In teaching vocabulary there are many kinds of media that can be used to increase students' vocabulary mastery. The teacher should know about that appropriate media and how implemeting those are in the classroom so that thes tudents can interest to learn English in general and vovabulary in particular. Crossword puzzle is a media which write the words accros and down which are the answer of the questions based on the clue.
Willey (2010) state that crossword puzzle is an arrangement of numbered squares to be filled in with words, a letter each square, so that a letter appearing in a word placed horizontally is usually also part of a word placed vertically : numbered synonyms and definitions are given as clues for the words. Crossword puzzle is in which word have to be written vertically (clue down) and horizontally (clue across) in a space of on check square. Therefore cross word puzzle is a puzzle that can be written in a space grid vertically and horizontally by guessing the clues.

When playing crossword puzzle, the learner must fulfill the blank space, the learner think to find out the word based on the clue. Puzzle helps the learner increase their vocabulary. Crossword puzzle is media that has good function in learning English. The effective function is the name of points out of important function that can be served through crossword puzzle.

Based on the statement above it can be conclude that Crossword Puzzle is a media that can increase the students' vocabulary. The students will find the new word by playing crossword puzzle. The enjoyable media may make the students interested to study English and they can remember new vocabulary. Crossword puzzle is a media that fill the word in the square which are the answer of the question based on the clue. There are word have to be written vertically of clue down and horizontally or it called clue across. It means that crossword 
puzzle will make the students enthusiast to learn English. While the students play crossword puzzle they may find new word in English so that it can increase their vocabulary.

\section{Developing English Media} Learning For Vocabulary Mastery Based on Crossword Puzzle Book.

Vocabulary mastery is one of the way to get the information or share the information to other people. The students are expected to get the messages or information from their vocabulary mastery. Summer (1999; 11) states vocabulary mastery is important to make people become an open minded.

Mastering vocabulary is not easy. This is because when the students want to learn they find the difficulty materials. Sometimes the materials is too difficult to be understood and make students confused and bored. Developing English media is one of the ways to make students understand easier. When playing crossword puzzle, the learner must fulfill the blank space, the learner think to find out the word based on the clue. Puzzle helps the learner increase their vocabulary. Crossword puzzle is media that has good function in learning English. The effective function is the name of points out of important function that can be served through crossword puzzle.

Considering the explanation above, it can be concluded that developing English media is important in order to get students' understanding. There are positive effects of crossword puzzle book in concerning vocabulary mastery. It makes students think critically.

\section{RESEARCH METHOD}

The type of research that is conducted by the researcher is developmental research. The research is not meant to generate a theory or verify one. In this research, the researcher uses formative research as the research design. It means that development is to provide the picture media and support the teaching vocabulary.

Further, it is a culmination task for the researcher so that she can finish the research marked with the approval of this $\mathrm{R}$ and $\mathrm{D}$ research. In addition, it is believed that the students will be interested to learn about vocabulary by using crossword Puzzle as media that use to increase the students' vocabulary mastery. Crossword puzzle make the students enjoy and fun in teaching learning process. They will more active and interest in learning English especially in vocabulary. Thus the students can master the vocabulary well.

The steps of this research are adapted from research and development (R\&D) steps by Tessmer $(1993 ; 17)$. There are four steps in formative research; self evaluation, expert review and one-toone, small group, and the last is field test. The development steps of evaluation are below: 


\section{Design of R\&D}

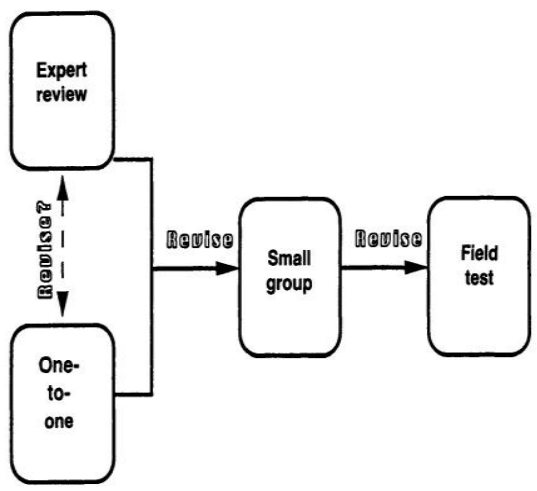

Figure 1. Instructional Design Flow Chart by Tessmer $(1993 ; 17)$

According to the Tessmer's opinion above there are some steps of development evaluation. The steps are expert evaluation, one-to-one, self evaluation, small group and field test. In this case all of the evaluation steps are used on the procedure.

Based on the research design above, there are four steps in formative research, they are: self evaluation, expert review and one-toone, small group and the last is field test.

\section{Self Evaluation}

This step consists of analysis and design steps. Analysis step is the first starting point in development research. In this step the researcher analyze the curriculum, contents, and literature which should appropriate to the curriculum of English education program at seventh grade in junior high school. Students' characteristic was also analyzed in this step. It produces various prototypes such as the first prototype of the self evaluation, second prototype of revision, expert review, and one-toone, and the third and the last prototype is from the revision in small group. The focuses of each prototypes are readability and applicability.

\section{Expert Review}

The outcome of the first prototype is derived from self evaluation. The expert will review the result, expert review, and two students will observe, commenting, and suggesting the product. The researcher can revise and improve the product after this step. The reviews by the expert do by the step as follow:

a. The researcher invite some expert of the subject study, expert of other development, expert of media product.

b. The researcher explain the process that implemented in the developing evaluation product to the expert.

c. Ask comment from the experts about the quality of the developing evaluation product by use some ways; give quetionare to fill up, interview abd disccusion about the quality of the product.

The review activities above the researcher should be accept the possibility all comment from the expert. As long as the review, the researcher just asked the clarity about the expert opinion feels like not clear or not relevance. The right attitude to refused or accept the expert opinion must be determine by the researcher itself after finishing the review.

\section{One-to-One}

The one-to-one do by the researcher with about two students individually. The students that chosen are should 
have a target population characteristic. The purpose of this step is to identify and minimize the shortages which are obviously founded in the evaluation product. The One the other way, this step aimed to get the students comments about the media that given. The steps of one-to-one implementation are as follow:

a. The researcher explain the purpose of the evaluation to the students, and need to get the students comments about the product that the researcher has developed.

b. The resercher motivated the students to follow the research as well with the right time that researcher needed. The researcher ask the students to understand the product and disscuss about the product.

c. In the last session the students asked to do the media which is chosen by the researcher.

d. The researcher motivative the students to give comments about the evaluation ectivities that they followed.

e. The researcher write the students comments and concluded the the implication of revision to the whole activities including to the product.

\section{Small Group}

After the product revised by the oneto-one steps, the evaluation product will be evaluated anymore with small group. The researcher takes some students, at least five, to be attempt the product. Every students will give comment to the product after the revision of the expert and one-to-one. This result will produce the third prototype after the second prototype in the review of the expert and oneto-one step.

This step is very important for this research. It determines the result of the product, how suitable the product is, and how the effect of the product to the student is. The end of the trying of the product, the students will answer some questions of the questionnaire whether to know the readability, applicability, and conspicuousness of the product. Otherwise, the researcher have to be proud in getting information about the shortages of the evaluation product because the researcher have the basis to revise it. The researcher should know, because the best product also still can be enhanced the quality of it product.

\section{Field Test}

After revised based on the input of small group, the evaluation product tested in the field test as the last step in the evaluation. The porpuse of the field test is to identify the shortages of media product and other purpose to produce a media facilitating the students to learn more vocabulary, the researcher will focus with the product applicability andreadability.. This research is checking the effectiveness to the students. The researcher will only analyze the applicability and readability questionnaire.

\section{FINDING AND DISCUSSION}

The researcher had hold an field test in different respondent. Based on the chart below, it can be shown that the result readability in the small group test was lower than the field test. The 
result of small group test is in blue line and the field test is in red line.

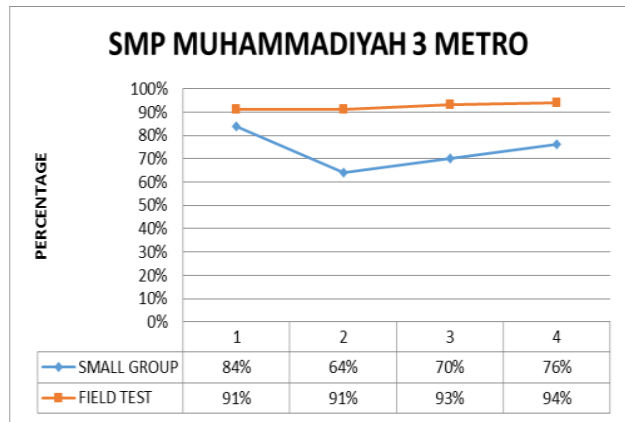

Chart 1. The comparison of Readability Result in the Small Group and the Field test in SMP Muhammadiyah 3 Metro

In the first place which is SMP Muhammadiyah 3 Metro, most of the result of field test was higher than small group. First, the score of word choice in small group is $84 \%$ and field test was $91 \%$. Second, the result of content in the small group was $64 \%$ and the result in the field test was $91 \%$. Third, the result of instruction based on crossword puzzle in blue line was $70 \%$ and in the red line was $93 \%$. It was good, the result of it was reach the target. Fourth, the result of layout in the small group was $76 \%$ and in the field test was $94 \%$.

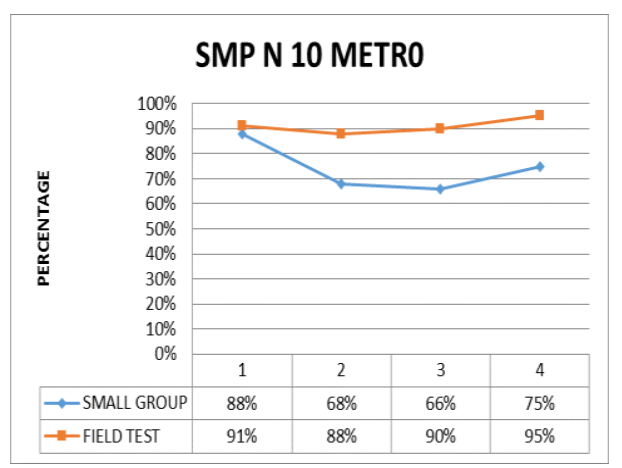

Chart 2. The comparison of Readability Result in the Small Group and the Field test in SMP Muhammadiyah 10 Metro

In the second place which is SMP N 10 Metro, most of the result of field test was higher than small group. First, the score of word choice in small group is $88 \%$ and field test was $91 \%$. Second, the result of content in the small group was $68 \%$ and the result in the field test was $88 \%$. Third, the result of instruction based on crossword puzzle in blue line was $66 \%$ and in the red line was $90 \%$. It was good, the result of it was reach the target. Fourth, the result of layout in the small group was $75 \%$ and in the field test was $95 \%$. It means that the result of field test was higher than small group.

Crossword puzzle is the teaching of content or information in the language being learned with little or no direct explicit effort to teach the language itself separately from the content being taught. The focus of the developing vocabulaary book as media for vocabulary mastery based on crossword puzzle are showing a good material, exploring students knowledge, and the student interesting with the product of crossword puzzle. The objective of this research is to know the contents of vocabulary included in crossword puzzle, to know how the content vocabulary are arranged in crossword puzzle, to know the result description of field test using crossword puzzle.

The material product by using crossword puzzle is made to explore the students knowledge by some activities on the material based on their ability. They will become active, fun, and enjoyable. So, by doing the activity, students can master the vocabulary easily.

Based on the questionnaire given for the seventh grade students of SMP Muhammadiyah 3 Metro and SMP Negeri 10 Metro, the product of 
vocabulary book as media for vocabulary mastery based on crossword puzzle was made as very good as possible. And serve a good material about vocabulary. It is make the students easily to understand the matrial of vocabulary and help them to master the vocabulary. Also make the students active in leraning. From the result of questionnary, it can be known that the students can increase their vocabulary.

\section{CONCLUSION}

Referring the problem formulation of this study, the result show that the researcher can develop vocabulary book based on crossword puzzle as media are arranged based on the material of vocabulary for seventh grade of junior high school. Vocabulary book based on crossword puzzle for vocabulary mastery was made as perfect as possible to get the students attractive and understanding. The researcher repaired vocabulary book based on crossword puzzle as media for vocabulary mastery in some aspect based on expert suggestion. Those are, the chosen of the cover picture should suitable with the material include in the chapter, the people's name that used in the dialogue should used Indonesian name. The instruction in every exercise must be clear and hidden word should make it easier so the students will easy to understand. The researcher should add more material before exercise and gave the suitable picture based on material explain. The last is clues in every crossword puzzle must be simpler and change the suitable picture that can draw someone's profession, so the students will not confuse.

All of the result of readability in small group, all the students had a good respect to do this research. The researcher gave readability and implement ability questionnaire to the students. The score of readability is good and it increased the prototype. Result of implement ability is good. It can provide the prototype.

In field test, the score of each questionnaire is very high, and the researcher got a good response of students. The material product is added more material and exercise also use suitable crossword puzzle to make students interesting. The students got a new knowledge and can master the vocabulary easily in the material product.

Based on the result above the researcher conclude that the content of vocabulary book based on crossword puzzle as media for vocabulary mastery can help students in learning vocabulary, arranging content of vocabulary are suitable with the syllabus and the material for seventh grade of junior high school, and the description result on field test using vocabulary book based on crossword puzzle is very good and can help students in learning vocabulary and the students got a new knowledge.

\section{REFERENCES}

Ceccony. (2007). Formative Evaluation Report. Nova Southeastern University Gobbio. 
Daryanto. (2013). Media Pembelajaran. Yogyakarta. Gava Media.

Hornby, AS. (2000). Oxford Advanced Learner's Dictionary. New York : Oxford University.

Ruis N. Muhyidin. Waluyo T. (2009) Instructional Media. Jakarta : Ministry of National Education.

Ricard. (2006). Approches and Methods in Language Teaching. Cambridge University Press.

Sugiyono. (2009). Metode Penelitian Kuantitatif, Kualitatif, dan $R$ \& D. Bandung: Alfabeta.

Summer. (1999). Introduction to Vocabulary Matery. Canada : National Literacy Secretariat.

Tanto. Widyas. Fahri. (2014). Developing English Learning Material For Vocabulary Mastery Based on Word Games Technique at First Semester of Eleventh Grade of Senior High School. Muhammadiyah University.

Tarigan (1986). The Improving of Students Skills by Crossword Puzzle to Describe of Animals and Plants For English Material of Seventh Grade. MTs Muhammadiyah Pekajangan.

Tessmer, Martin. (1993). Planning and Conducting Formative
Evauation. London: Kogan Page Limited.

Universitas Muhammadiyah Metro. (2012). Pedoman Khusus Penyusunan Skripsi Program Studi Pendidikan Bahasa Inggris Edisi Revisi 2010.Metro: $\quad$ Universitas Muhammadiyah Metro.

Wallance, M. (1998). Teaching Vocabulary Education Limited. New York

Willey, J. (2010). Webster's new world college dictionary: Retrieved May 2013 from http://www.yourdictionary.co $\underline{\mathrm{m} / \mathrm{cr} \text { ssword-puzzle. }}$ 